\title{
The Independency of the Corruption Eradication Commission of the Republic of Indonesia (KPK RI) in Indicators of Independent Regulatory Agencies (IRAs)
}

\author{
Rizki Ramadani, Moch. Andry W.W. Mamonto \\ Faculty of Law, Universitas Muslim Indonesia \\ email: rizkiramadani18@gmail.com
}

\begin{abstract}
This research aims to know, analyze, and formulate the independency indicators of independent institutions based on the concept of Independent Regulatory Agencies (IRAs) in advanced countries (United States and Europe). Also as an efforts to examine and see the extent to which independent institutions in Indonesia meet these indicators. This study focuses on KPK institution that are well known as one of independent institutions in Indonesia. Although in practice it often rise the controversy and resistance from many parties. The method used in this legal research is normative legal research, conducted through literature study or secondary data. Data consists of legal materials primary, secondary and tertiary, which are then processed descriptive-prescriptively. The research also uses several approaches such as legal, conceptual, and case approach.
\end{abstract}

Keywords: Independent Regulatory Agencies (IRAs), Independence, KPK

\section{INTRODUCTION}

Compared to the United States, it can be argued that the term Independent State Institution (LNI) in the context of indonesia doesn't have any meaningful justification. This is because until the present day there has not been a single article in the legislation which mention the term " independent state " definitively. in the early time of the UUD NRI 1945 (1945 Constitution) formulation, the LNI has not yet found a place of discussion in the constitutional format. ${ }^{1}$ Even the term state institution itself has not been discussed. While the 1945 Temporary Constitution (UUDS), used the term "state equipment" to define state institutions, but still has not specifically embedded the word "independent". The legitimacy for the establishment of independent state institution (LNI) just gained quite good sentiments only after the amendment of the 1945 Constitution. $^{2}$

The Corruption Eradication Commission (KPK), for example, in Article 3 of Law No. 30 Year of 2002 regarding the Corruption Eradication Commission, states that the Corruption

'Zainal Arifin Mochtar, (2016), Lembaga Negara Independen: Dinamika Perkembangan dan Urgensi Penataannya Kembali Pasca-Amandemen Konstitusi, Jakarta, Rajawali Pers, page 5.

${ }^{2}$ Ibid.,page 4-6. 
Eradication Commission is a State institution which in carrying out its duties and authorities is independent and free from any influence of power. There is no formulation or further explanation regarding the independent aspect which has been mentioned. In fact, when the KPK translated the word 'independent' in the form of concrete actions against various corruption cases, controversy arose. Even by some parties it is often regarded as a form of arrogance by the superbody institution.

Related to the phenomenon above, it becomes important and strategic to formulate measurable standards of independency for independent institutions. It is also interesting to examine the independency of independent institutions in Indonesia by by referring to the institutional concept and design in Europe and United States. This review will focus on the institutional and independency aspects of KPK as one of the independent state institutions in Indonesia.

\section{METHOD}

As a legal research, this research is a study of the concept of independency and institutional independence. Thus this research requires secondary data from literature studies. Based on this, this research is included in the type of normative research. From its nature, this research is descriptive-prscriptive. information from various aspects of the issues discussed in this research, this research uses several approaches, such as statutory approach, second, case approach, third, conceptual approach.

\section{ANALYSIS AND DISCUSSION Independent Regulatory Agencies (IRAs) Indicators as Indicators of Independent State Institutions (LNI) in Indonesia}

In contrast to the existence of Independent Institutions that are still vague in Indonesia, the opposite can be found in the United States and Europe. Where independent state institutions or commonly called Independent Regulatory Agencies (IRAs) are legally guaranteed by the legislation and even explicitly and limitatively mentioned. This exist for example in the provisions of The Paperwork Reduction Act44 (U.S.C. § 3502), which in point (5) states;

"The term "independent regulatory agency" means the Board of Governors of the Federal Reserve System, the Commodity Futures Trading Commission, the Consumer Product Safety Commission, the Federal Communications Commission, the Federal Deposit Insurance Corporation, the Federal Energy Regulatory Commission, the 
Federal Housing Finance Agency, the Federal Maritime Commission, the Federal Trade Commission, the Interstate Commerce Commission, the Mine Enforcement Safety and Health Review Commission, the National Labor Relations Board, the Nuclear Regulatory Commission, the Occupational Safety and Health Review Commission, the Postal Regulatory Commission, the Securities and Exchange Commission, the Bureau of Consumer Financial Protection, the Office of Financial Research, Office of the Comptroller of the Currency, and any other similar agency designated by statute as a Federal independent regulatory agency or commission". ${ }^{3}$

Under these provisions, it can be known immediately that there are at least nineteen state institutions which explicitly designated as independent state institutions or IRAs. Thus exist a role model or blue print regarding what Independent Regulatory Agencies refer to in the context of the United States. In contrary, other institutions which are not included in the provisions or their institutional characteristics are not entirely the same, not included as the IRAs.

The institutional design of IRAs or independent institution in the United States as proposed by Funk and Seamon, elaborate the characteristics of IRAs into the following elements;

"These characteristics are (1) They are headed by multi-member groups, rather than a single agency head; (2) no more than a simple majority of these members may come from one political party; (3) the member of the group has fixed, staggered tems, so that their terms do not expire at the same time; and (4) they can only be removed from their position for "cause", unlike most executive officials, who serve at the pleasure of the president."

While Zainal Arifin Mochtar as he quoted fro, Milakovich and Gordon describes some of the characteristics of American and European independence Institution as follows;

1) The institution has collegial leadership, so decisions are taken collectively.

2) The members or the commissioners of the institution do not serve what the president desires.

\footnotetext{
${ }^{3}$ More see "The Paperwork of Reduction Act of 1980". As quoted from https://www.law.cornell.edu/uscode/text/44/3502 This regulation is essentially designed to lighten the administrative burden of government agencies in the private sector by delegating such authority to institutions outside the executive. All of these rules contain procedural requirements for such institutions in exercising their authority. See https://en.wikipedia.org/wiki/Paperwork_Reduction_Act ${ }^{4}$ William F. Funk dan Robert H. Seamon, 2001, Admisnistrative Law: Examples and Explanations, Apen Law \& Bussiness, Printed in the United States of America, New York, page 7.
} 
3) The commissioner's term of office is usually definitive and long enough, for example 14 years for the period of the Federal Reserve Board in America.

4) The period of his position is "staggered". That means, every year each commissioner changes gradually and therefore, a president can not fully control the leadership of the relevant institutions.

5) The number of members or commissioners is odd and decisions are made by a majority of the votes

6) Membership of this institution usually maintains a representative partisan balance ${ }^{5}$.

Thatcher, who analyzed the phenomenon of IRAs in Britain, France, Germany and Italy, drew the conclusion that there are three most important aspects of IRAs, namely the independence of elected officials, relationships with other administrative institutions (regulatees), and decision making process. He then explained that the independence of IRAs in practice can be seen from five indicators which are; ${ }^{6}$

1) Party Politicisation of appoinments, which means the greater politicization towards IRAs, the smaller its independence. it also affects greater oversight by elected officials (executive / parliament).

2) Departures (dismissal and resignation), ie the dismissal of IRAs members before the end of the term of office, the more frequent and rapid the dismissal, the lower the independence.

3) The Tenure of IRA members, the longer their tenure, the greater their independence to the elected officials.

4) The financial and staffing resources of the IRA, namely independence in terms of finance and resource management.

5) The use of power to overturn the decisions of IRAs by elected politicians, ie the extent to which government officials are able to change the IRAs' decisions and policies.

In addition to institutional characteristics, independence is also manifested in the characteristics of the authority possessed by the LNI. In the United States, there are many federal government bodies granted constitutional authority by legislatures (through law) to exercise power independently. These federal agencies practically carry out government

${ }^{5}$ Zainal Arifin Mochtar Husein, dkk., "Efektifitas Sistem Penyeleksian Pejabat Komisi Negara," Final Report Penelitian, kemitraan partnership, 2008, page 11.

${ }^{6}$ Mark Thatcher, "Independent Regulatory Agencies ini Europe", downloaded from http://www.hec.edu/heccontent/download/3643/137514/version/2/file/Thatcher.pdf pada 18 mei 2016. 
functions by combining the legislative, executive and judicial powers. Regarding this quasicharacteristic authority Funk and Seamon point out;

"Specifically, an agency may have (1) the "quasi-legislative" power to adopt regulations that control people's everyday conduct; (2) the executive power too enforce those regulatios and ther law that he agency is responsible for administering; and (3) the quasi-judicial power to apply those regulations and laws in individual cases....some agencies not only combine powers resembling those of the three separate branches but also are somewhat insulated from presidential control, these are called "independent agencies".."

In American and European countries, It's widely known that the state institutions which categorized as IRAs have regulatory authority or rule making function. ${ }^{8}$ This "self regulatory" characteristic is one of the elements of IRAs in beside the independency.

Based on several concepts and models of independence initiated by the experts above, the authors intend to integrate these views in order to establish an ideal standard of independence according to the concept of Independent Regulatory Agencies (IRAs). This independence standard will be used as an indicator in analyzing and examining the independence aspect of KPK institution which becomes the object of study in this research. Those indicators of independence are formal independence (formal independence) aspects which includes;

1) Personnel independence, which consist of several aspects namely;

a. Appointment and dismissal protection, ie mechanism for the appointment and dismissal of the institution's head under certain causation stipulated in law, thus not depending on the will of the president alone.

b. Multi-member groups, namely the Leadership model that plural or collective leadership is composed of several people with decision making that is collegial

c. Nonpartisan members; Leadership that is not majority and not dominated from one party or certain group

d. Definitive terms of Office; namely the defined and definitive term of office of the member.

2) Functional Independence, consisting of;

a. Regulatory Authorities / Quasi Legislative power; namely having the authority of rulemaking or stipulating regulations in certain fields mandated and established by law.

\footnotetext{
${ }^{7}$ William F. Funk dan Robert H. Seamon, Op.cit.,hlm. 23-24.

${ }^{8}$ Fabrizio Gillardi, 2008, Delegation In The Regulatory State, Independent Regulatory Agencies In Western Europe, Edward Elgar Publishing Limited, United Kingdom, page. 22.
} 
b. Sanctioning Authorities / Quasi judicial power; ie whether an LNI has the authority to independently conduct investigations, prosecutions, imposition of sanctions or other authorities relating to judicial functions.

3) Institutional Independence, which consisting of;

a. Financial and Organizational management; namely whether the institution have independence in regulating and determining budget and managing internal affairs.

b. External Relation; namely the mechanism of inter-institutional relations. The extent to which the LNI independent from influence and dependence with other institutions.

In addition to the formal independence aspects above, the analysis will also be conducted towards the aspects of informal independence (de facto independence). This is done by applying case study approach to several aspects of the authority implementation and real condition of the institution. Some concepts from Mark Thatcher are used as indicator of analysis which are;

1) Politicisation of appoinments, ie to see if there is politicization in terms of appointment of the leadership of the institution.

2) Departures (dismissal and resignation), ie how often the chairman of the institution stepped down from office before his term ended.

3) The use of power to overturn the decisions of IRAs, ie the extent to which other institutions are able to change and influence the decisions or policies of the LNI.

\section{The Formal Independence of Corruption Eradication Commision Republic Of Indonesia (KPK RI)}

Speaking about KPK as independent state institution (LNI), the aspect of formal independence are institutionalized and reflected in it's legal provision which is Law no. 30 of year 2002 concerning the Commission for the Criminal Act of Corruption. Based on the formal independence indicator in the concept of Independent Regulatory Agencies or IRAs which are consisting of personnel independence, functional, and institutional aspects and their respective elements, the independence of KPK can be seen in the following table; 
Tabel 1.

Formal Independence of KPK

\begin{tabular}{|c|c|c|c|}
\hline Independency Aspect & $\begin{array}{c}\text { Elements of } \\
\text { Independency }\end{array}$ & $\begin{array}{c}\text { Exist/ } \\
\text { Not exist }\end{array}$ & Legal provision \\
\hline personel independence & $\begin{array}{l}\text { Appointment and } \\
\text { dismissal protection }\end{array}$ & Exist & $\begin{array}{l}\text {-Article } 32 \text { (1) The Chairman } \\
\text { of the Corruption Eradication } \\
\text { Commission shall cease or be } \\
\text { dismissed for: a. die; b. } \\
\text { termination of his office term;c. } \\
\text { become a defendant for } \\
\text { committing a criminal offense; } \\
\text { d. remain unattended or can } \\
\text { not perform its duties } \\
\text { continuously for more than } 3 \\
\text { (three) months; e. resign; or } \mathrm{f} \text {. } \\
\text { subject to sanctions under this }\end{array}$ \\
\hline
\end{tabular}

Act.

- Article 22 (2) The selection committee shall be established by the Corruption Eradication Commission.

- Article 30 (1) The Chairman of the Corruption Eradication Commission shall be elected by the Congress of the Republic of Indonesia among the candidate proposed by the President of the Republic of Indonesia.

\begin{tabular}{ll}
\hline $\begin{array}{l}\text { Multi member } \\
\text { groups }\end{array}$ & - Article 21 (1) The Corruption \\
& Eradication Commission shall \\
& consist of: the Chairman of the \\
& Corruption $\quad$ Eradication \\
& Commission consisting of 5 \\
& (five) internal members.
\end{tabular}

- Article 21 (5) The boards of Chairman of the Corruption 


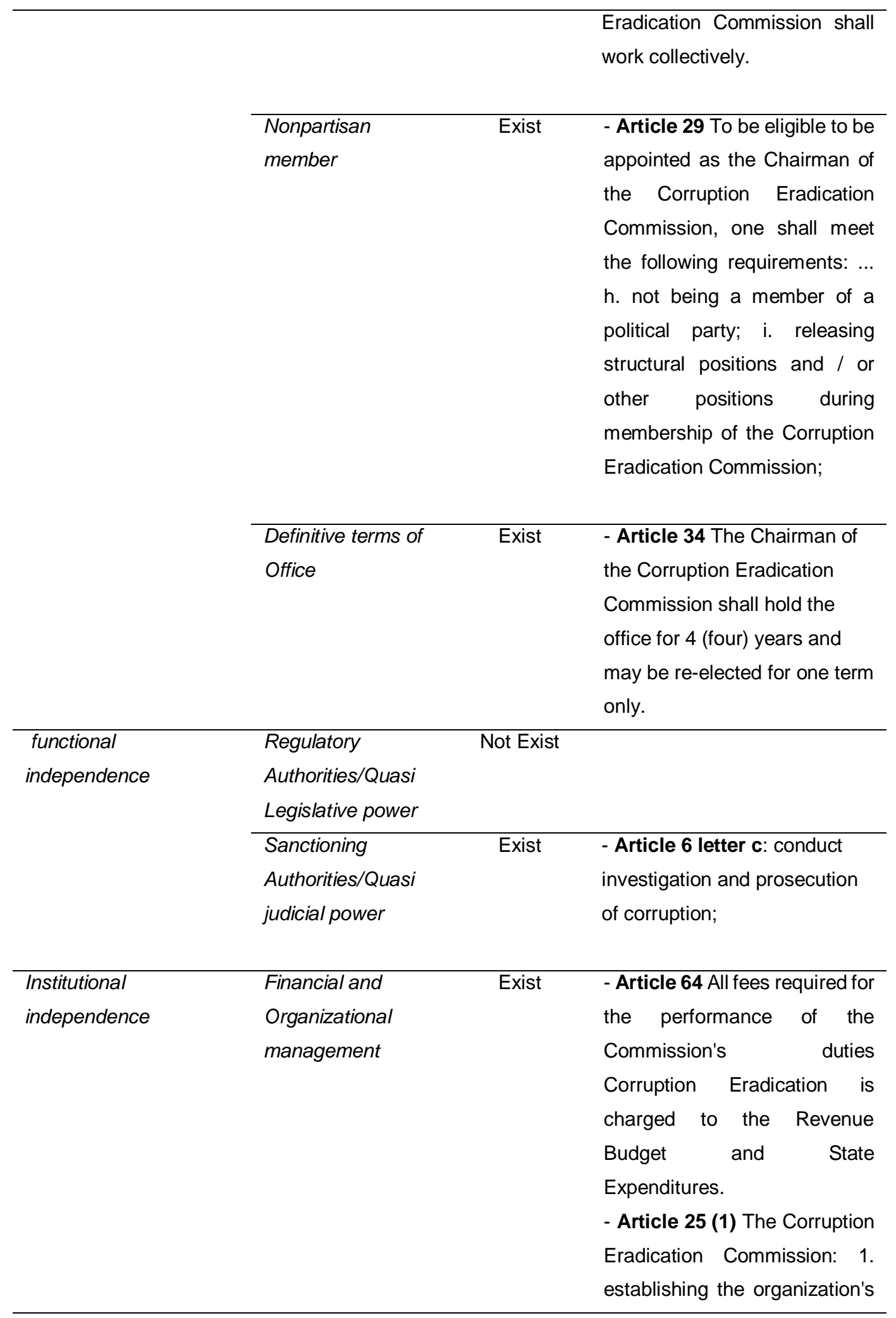




\begin{tabular}{ll}
\hline policy and organization on the \\
implementation of the duties \\
and authorities of \\
KPKCorruption; 2. appoint and \\
dismiss Head of Division, Head \\
of Secretariat, Head of Sub- \\
Division, and officer in chargeto \\
the Corruption Eradication \\
Commission;
\end{tabular}

Based on Table 1 it can be seen that the institutional design of the Corruption Eradication Commission as contained in the provisions of Law 30 of year 2002 almost fulfill all of formal independence indicators in the concept of IRAs. In terms of personnel independence, the KPK has met the mandatory requirement to be categorized as IRAs, referring to the mechanism of removal protection, ie the regulation concerning dismissal of 'certain causes' which does not depend on the 'political taste' of the President. Similarly, the collegial leadership model and the collective decision making process.

Nevertheless, although in the selection of the commissioners involving a committee chosen by the KPK itself, the final decision to vote is still in the hands of the DPR (congress). Makes it a big potential for politicization towards the candidates for by the politician. In fact, congress will generally vote for the same candidate based on political preference, or at least as appropriate to their interests. The authority of the Legislative Assembly to elect its own 
public officials is still rising a debate in the context of constitutionality, since it is basically the authority of the President as the hig hest executive officer or head of government to do so.

In the aspect of functional independence, unfortunately the KPK has no authority in regulatory or rulemaking, which is one of the important aspects of IRAs. Its tasks, authorities and functions have been implemented based on existing regulations spread in Corruption act, KPK act and general provisions on criminal law procedure. However, basically quasi-judicial authority such as investigation, prosecution and supervision over other institutions in the case of corruption crime is sufficient to classify the KPK as an independent institution.

The formal independence of the KPK also exists in terms of organizational and staffing that can independently managed by the it's own. Thing is also supported by the budget which allocated directly from the APBN (State Budget of income and expenditure). From a relational perspective to other institutions, the KPK's responsibility to provide an annual report to the President, including the House of Representatives (legislative branch) and also audited by BPK, doesn't indicating the dependence of KPK to other organs. in fact, it is necessary to ensure the institution's accountability to the public. It's also used as a control mechanism of the people's and the government in assessing KPK's performance in general.

\section{De facto independence of KPK}

It must be acknowledged that behind the institutional design of the Corruption Eradication Commission (KPK) which almost entirely in accordance with the concept of independent state institutions in the modern era (IRAs), its existence in Indonesia is the most often reaping conflict and being exposed to various problems. Since the Antasari Azhar Leadership, the term "lizard vs. crocodile" emerged as an analogy of the KPK conflict against the POLRI. The course of this conflict then not only happened once, but up to three times (Volume I, II, III in the language of the media) in every change of KPK management. The conflicts which occured varies from the issue of criminalization, to the investigation authority dispute between two institutions. ${ }^{9}$

\footnotetext{
${ }^{9}$ For example after the conflict of "lizard vs. crocodile" (volume I) in July 2012, the dispute between KPK vs. Police was reopened (Volume II), after KPK appointed former Chief of Police Traffic Corps Inspector Djoko Susilo as suspect of corruption case in SIM simulator project. In fact, before the Police Headquarters has stated, after investigating the internal investigation, did not find the element of corruption in the project, involving Djoko Susilo There was a dispute over the authority between the KPK and Police in investigating the corruption case. While in the third conflict, beginning with the determination of the suspect by the Commission against Komjen Budi Gunawan who is a candidate for Chief of Police. In the aftermath of this long feud, two KPK commissioners, Abraham Samad and Bambang Widjoyanto, were arrested by the Police Criminal Investigation Unit (Police Criminal Investigation Unit) each with a family card case and alleged witness briefing by BW when handling election dispute cases in the Constitutional Court. Automatically both are disabled as KPK leaders. While on the POLRI, Komjen Budi Gunawan canceled off as the Chief of Police was replaced by Baddrodin Haitian commander. See Tempo Magazine, "Sim Salabim SIM Simulator", 23-29 April 2012 edition.
} 
In practice, it can be concluded that in terms of the de facto independence, KPK has great constraints in the aspect of The use of power to overturn the decisions of IRAs, as proved by the frequent intervention of POLRI in the exercise of the KPK's authority. Whereas specifically in corruption, the act regarding KPK has determined that it has supervision authority over other institutions. This agency's intervention has not been included from the alleged effort of systematic weakening against KPK by the legislative through revision of KPK and KUHAP regulation. For example with the proposal to revoke KPK's authority in recruiting independent investigators, and forming an executive council that acting as extension of the president's hand to control and oversee the performance of the KPK. ${ }^{10}$ The idea of revision on the Corruption Eradication Commission by legislative which is non-transparent and not disclose will affect the existence of KPK as law enforcer. ${ }^{11}$ Recently, the public was also preoccupied with the question of the right of inquiry submitted by the legislative (DPR) against the KPK, which then led to the final decision by the Constitutional Court allowing such action. In the Departures (dismissal and resignation) indicators, the KPK was reaping very bad results. Throughout the KPK's record, there were several commissioners who were disbanded before their term ends. among them is the former KPK Commissioner Antasari Azhar, who was found guilty of a crime of premeditated murder.In KPK volume II, commissioners Chandra Hamzah and Bibit Waluyo also had dimissed in charge of the bribery case. In addition, there is also Abraham Samad, former chairman of the Corruption Eradication Commission in the third regime who was hit by a family card forgery case, and Bambang Widjoyanto who holds the status of a suspect in Bareskrim POLRI for the case of witnesses manipulation. Both are dismissed by the President, even though the provisions state that Commissioner can only be dismissed if he/she has bear the status of a defendant. In the aspect of Politicisation of Appoinments, the discourse of the politicization of KPK began to emerge since the election of the KPK in $2016^{12}$, where the names are predicted to be strong and have a good track record was not removed by the House. There are allegations that the House of Representatives tends to vote for one candidate with the same agenda and interests of the House. ${ }^{13}$ Particularly in the election of Basaria Panjaitan with the background of POLRI, it is considered that the public is not in line with the effort to independent KPK from the influence of POLRI.

\footnotetext{
${ }^{10}$ Lihat http://www.cnnindonesia.com/politik/20151007125208-32-83389/icjr-dewan-eksekutif-intervensi-pemerintahdi-kpk/ lihat juga https://nasional.tempo.co/read/news/2012/03/14/063390078/ada-upaya-dpr-terus-intervensi-kpk

${ }^{11}$ Indriyanto Seno Adji, "Inisiatif Pelemahan atau Penguatan KPK?" article in Harian Suara Pembaruan, Friday, 12 February 2016.

${ }_{12}^{12}$ http://nasional.kompas.com/read/2015/12/18/07585511/.Komposisi.Pimpinan.Terpilih.KPK.Mengkhawatirkan.

${ }^{13}$ See http://news.liputan6.com/read/2391399/abdullah-hehamahua-dpr-bakal-pilih-pimpinan-kpk-sesuai-selera
} 


\section{Volume I, Issue 2, July 2018 : 82 - 94}

Tabel 2.

De facto Independence of KPK

\begin{tabular}{ll}
\hline \multicolumn{1}{c}{ Independency Elements } & \multicolumn{1}{c}{ Description } \\
\hline Politicisation of appoinments & $\begin{array}{l}\text { Politicisation by legislative in the selection } \\
\text { process of commissioner candidates. }\end{array}$ \\
\hline Departures (dismissal and resignation), & $\begin{array}{l}\text { Some of KPK Commissioners are dismissed } \\
\text { before the office term due to criminal cases. }\end{array}$ \\
\hline The use of power to overturn the decisions & $\begin{array}{l}\text { Intervention to KPK's authority by National Police } \\
\text { of IRAs }\end{array}$ \\
& Department, ressitance and some efforts to \\
& weakening the institution by the legislative.
\end{tabular}

KPK commissioner selection has always been a problem. One of them was when the Antasari Azhar Corruption Eradication Commission (KPK) candidate was reported to the Supervisory Section of the AGO on the alleged violation of the code of conduct of the prosecutors by a number of students who joined in the Anti-Manipulation Student Movement (Geram BUMN). In other cases, a pattern that threatens the independence of KPK's filling position has also been conducted by the President against the KPK, which at that time was short of commissioners. As known, the appointment of KPK commissioners as an independent institution requires them to be elected through selection mechanisms, but the President actually issues a PERPPU which in principle enlarges the president's authority to appoint KPK commissioners. If the recruitment mechanism is not corrected immediately, the politicization of KPK commissioner elections will clearly affect the level of independence as an LNI.

\section{CONCLUSION}

Based on the description above, the independence of an independent institution or LNI can be divided by two indicators. First, the formal independency which includes aspects of institutional design. This formal indicator can also be used as a reference or blueprint for the future establishment of independent institutions in Indonesia. Secondly, non-formal or de facto independence, which used as indicators in practice, such as politicization election, and external resistance. In the context of the KPK, there has been no correspondence between the formal independence aspect and the implementation according to de facto independence.. The KPK's institutional design, which is formally very independent, yet has not been able to make the KPK truly independent in its implementation level. By that time, the government and the public must be more consistent and have greater commitment regarding to the position and guarantee the independence of KPK in the Indonesian state administration system. 


\section{REFERENCE}

Djanggih, H., Thalib, H., Baharuddin, H., Qamar, N., \& Ahmar, A. S. (2018). The Effectiveness of Law Enforcement on Child Protection for Cybercrime Victims in Indonesia. In Journal of Physics: Conference Series (Vol. 1028, No. 1, p. 012192). IOP Publishing.

Fabrizio Gillardi, (2008), Delegation In The Regulatory State, Independent Regulatory Agencies In Western Europe, Edward Elgar Publishing Limited, United Kingdom.

Qamar, N., Busthami, D., Aswari, A., \& Reza, F. S. (2017). Logika Hukum, Meretas Pikir dan Nalar, Social Politic Genius (SiGN), Makassar.

RAMADANI, R., Mochtar, Z. A., \& SH, L. (2016). Independensi Lembaga Negara Independen (Studi Dalam Konsep Independent Regulatory Agencies) (Doctoral dissertation, Universitas Gadjah Mada).

William F. Funk, dan Richard H. Seamon, (2001), Admisnistrative Law: Examples and Explanations, Apen Law \& Bussiness, Printed in the United States of America, New York.

Zainal Arifin Mochtar, (2016), Lembaga Negara Independen: Dinamika Perkembangan dan Urgensi Penataannya Kembali Pasca-Amandemen Konstitusi, Jakarta, Rajawali Pers.

Zainal Arifin Mochtar Husein, at.al. (2008). "Efektifitas Sistem Penyeleksian Pejabat Komisi Negara," Final Report Penelitian, kemitraan partnership.

Majalah Tempo, "Sim Salabim Simulator SIM", edisi 23-29 April 2012

Undang-Undang Dasar Negara Republik Indonesia Tahun 1945

Undang-Undang Nomor 30 Tahun 2002 Tentang Komisi Pemberantasan Tindak Pidana Korupsi 